\title{
MANAGEMENT OF CANCER OF UNKNOWN PRIMARY
}

\author{
IVA ANDRAŠEK ${ }^{1}$, MIRNA RAVLIĆ ${ }^{1}$, MARTINA MIKULANDRA ${ }^{1}$, FRANJO CMREČAK $^{1}$, \\ SARA BILIĆ KNEŽEVIĆ ${ }^{2}$ and LIDIJA BEKETIĆ-OREŠKOVIĆ ${ }^{1,3}$ \\ ${ }^{1}$ Division of Oncology and Radiotherapy, University Hospital for Tumors, \\ Sestre milosrdnice University Hospital Center, Zagreb, Croatia \\ ${ }^{2}$ Department of Oncology and Nuclear Medicine, Zadar General Hospital, Zadar, Croatia \\ ${ }^{3}$ Department of Clinical Oncology, School of Medicine, University of Zagreb, Zagreb, Croatia
}

\begin{abstract}
Summary
Cancer of an unknown primary site is most commonly an aggressive metastatic tumor with a median patient survival of 6 to 9 months. Histologically, it is predominantly adenocarcinoma, and if the primary site is subsequently diagnosed, it is usually the pancreas or lung. Biopsy should be performed whenever possible to classify a tumor of unknown primary origin into one of the following entities: adenocarcinoma, poorly differentiated carcinoma with characteristics similar to adenocarcinoma, squamous cell carcinoma, neuroendocrine carcinoma, poorly differentiated neoplasm. After determining the primary tumor type, the subtype is determined by immunohistochemical staining. In oligometastatic disease, there is a possibility of surgical treatment. Radiotherapy is used as a part of combined modality treatment. Most patients with cancer of unknown primary have an unfavorable prognosis despite multiple chemotherapy agents, and no protocol can be recommended as standard therapy.
\end{abstract}

KEYWORDS: cancer of unknown primary, prognosis, treatment

\section{INTRODUCTION}

Cancer of unknown primary (CUP) is a clinical-pathological syndrome characterized by histologically proven metastatic cancer without a clinically found primary site of origin (1). Most of these cancers have a primary occult site but with a metastatic ability (1). These tumors are considered aggressive, disseminate early, and with an unpredictable pattern, leaving these patients' life expectancy short, with a median survival of 6 to 9 months $(2,3)$.

In 2017, 604 newly diagnosed patients with cancer of unknown primary in Croatia accounted

Corresponding author: Lidija Beketić-Orešković, Department of Clinical Oncology, School of Medicine, University of Zagreb and Division of Oncology and Radiotherapy, University Hospital for Tumors, Sestre milosrdnice University Hospital Center, Ilica 197, 10000 Zagreb, Croatia.

e-mail: lidijabeketicoreskovic@gmail.com for $2.4 \%$ of all newly diagnosed cancer patients. $54.0 \%$ of these patients presented with distant metastases, and $27.1 \%$ of them with unknown disease stages (4). Histologically, most of the cancers of unknown primary are adenocarcinomas $(50-70 \%)$, fewer are undifferentiated carcinoma (20-30\%), squamous cell carcinoma (5-8\%), and undifferentiated tumors $(2-3 \%)(5)$. When and if the primary site is diagnosed, most common are pancreas $(20$ $26 \%)$, lung $(17-23 \%)$, liver (3-11\%), colon $(4-10 \%)$, gastric (3-8\%), kidney (4-6\%), ovary (3-4\%), prostate $(3-4 \%)$ and breast cancer $(2 \%)(6)$.

\section{Clinical presentation and prognosis}

Over $50 \%$ of patients with cancer of unknown primary have more than one site of metastatic involvement, mostly liver, lymph nodes, bones, lungs. This type of cancer can metastasize to any site, making the pattern of metastasis inadequate 
to determine tumor origin (7). The clinical presentation depends on metastases' location and can be followed by non-specific symptoms such as fatigue and weight loss. Most patients present with pain $(60 \%)$, enlarged liver or abdominal symptoms $(40 \%)$, palpable lymph nodes $(20 \%)$, bone pain or fracture $(15 \%)$, lung symptoms $(15 \%)$, or CNS abnormalities (5\%) (8).

In general, CUP prognostic factors that are considered negative are male gender; more than three metastatic sites; performance status two or more; metastases outside of lymph nodes; elevated LDH, lymphopenia, low serum albumins, and unfavorable CUP subset $(9,10)$.

\section{Clinical investigation}

Firstly, a thorough medical history, including family history, should be taken alongside a physical exam with an accent on breast, lymph node, skin, genitalia, rectum, and pelvis examination (11).

Complete laboratory workup should be performed, including full blood count, liver and kidney function tests, bone profiling, serum LDH, and urine test. The routine tumor markers CEA, CA 125, CA 19-9, and CA 15-3 are not advised as these markers are not specific enough. However, they can be useful in specific situations such as PSA tests in male patients with bone metastases, $\beta \mathrm{hCG}$ and $\alpha \mathrm{FP}$ in midline nodal disease, or CA125 in female patients with peritoneal malignancy and ascites (11).

Chest, abdomen, and pelvis CT is recommended for all patients with CUP. Endoscopy is advised based on clinical symptoms (11).

Positron emission tomography can be performed in selected cases (squamous carcinoma in cervical/inguinal nodes and those with a single site involved). If ordered, it should be performed before EUS or biopsy/FNA/tonsillectomy to identify potential primary sites before any intervention occurs. Mammography should be done in female patients, even a breast MRI if breast cancer is highly suspected. Other evaluation should be based on findings from the initial diagnostic evaluation, such as colonoscopy in patients with features associated with colon cancer (peritoneal/ liver metastases, biopsy CK20+, CK7-, CDX2+), bronchoscopy (patients with mediastinal/hilar adenopathy, biopsy $\mathrm{CK} 7+$ ), testicular ultrasound
Table 1.

IHC stain patterns of single cancer or tissue of origin.

\begin{tabular}{|l|l|}
\hline $\begin{array}{l}\text { Lung cancer } \\
\text { and large cell }\end{array}$ & CK7+, CK20-, TTF-1+, NapsinA+ \\
\hline Breast cancer & $\begin{array}{l}\text { CK7+, CK20-, GCDFP-15+, } \\
\text { mammoglobin+, ER+, PR+, GATA3+, } \\
\text { Her-2/neu+ }\end{array}$ \\
\hline Prostate cancer & CK7-, CK20-, PSA+, \\
\hline Germ cell & PLAP+, OCT4+, SALL4+ \\
\hline Melanoma & MelanA+, HMB45+, S100+ \\
\hline Colorectal cancer & CK7-, CK20-, CDX2+ \\
\hline
\end{tabular}

(young patients with mediastinal and/or retroperitoneal masses) and others (1).

A biopsy should be performed whenever it is possible. The light microscope classification of CUP includes adenocarcinoma $(60 \%)$, poorly differentiated carcinoma with features similar to adenocarcinoma $(30 \%)$, squamous cell cancer $(5 \%)$, neuroendocrine carcinoma $(3 \%)$, and poorly differentiated neoplasm (2\%). Additionally, immunohistochemistry (IHC) can be useful in obtaining an accurate diagnosis. Given the numerous IHC staining markers, a stepwise approach is advised. Firstly by determining the main type of cancer (carcinoma, lymphoma, melanoma, sarcoma), then identify the subtype using specific IHC staining based on the light microscope finding and clinical features. Gathering multiple stains usually consumes the sample and rarely improves the diagnosis. Table 1 shows IHC stain patterns of single cancer or tissue of origin $(1,12)$.

Several molecular assays are available in the USA based on the gene expression profile that provides a molecular classification of numerous cancer types with high accuracy rates (87\%-90\%) (1).

\section{Treatment}

CUP subgroups have been identified based on the patient's gender, metastatic sites, histologic classification, and IHC staining and molecular cancer classifier assays. For patients with a favorable prognosis, subgroup-specific treatment options based upon presumptive diagnoses exist. However, over $80 \%$ of patients fall into the unfavorable subgroup, where no efficient therapy has yet been identified. Some of the favorable subsets that will be described below include extragonadal germ cell cancer syndrome, axillary carcinoma in women, squamous cell carcinoma in upper cervi- 
$\mathrm{cal} /$ neck nodes and pelvic lymph nodes, men with osteoblastic metastases, and elevated PSA, neuroendocrine and peritoneal carcinoma $(1,9)$.

Extragonadal germ cell cancer syndrome is a rare subset mostly found in young men involving the midline distribution (mediastinal and/or retroperitoneum) of poorly differentiated carcinoma. However, even if the histology is atypical, germ cell carcinoma therapy is indicated (1).

Axillary carcinoma in women, rarely men, usually indicates occult breast cancer, with negative radiographic findings. These patients should be treated like stage II or III breast carcinoma, seeing as their prognoses are similar (1).

Squamous cell carcinoma in upper cervical/ neck nodes is highly suggestive of occult head and neck carcinoma, and the treatment depends on the $\mathrm{N}$ stage of the disease. N1 disease neck dissection is the preferred treatment (with adjuvant treatment depending on the postoperative pathology report), while $\geq \mathrm{N} 2$ can be treated surgically or using concurrent chemoradiotherapy (1). If definitive surgery is planned, a biopsy of suspected areas plus tonsillectomy for the occult primary is advisable. In inguinal or pelvic lymph nodes, squamous cell carcinoma most likely arises for an occult uterine, anal, or vulva primary. Combined modality therapy is recommended (1).

Men with elevated PSA levels and osteoblastic metastases should receive hormonal therapy for prostate cancer. Even men with osteoblastic metastases and normal PSA levels can receive hormonal therapy in selected clinical settings (1).

Treatment for neuroendocrine carcinoma depends on the tumor grade. Well-differentiated tumors are treated similar to carcinoid tumors. Poorly differentiated should be treated with cisplatin- or carboplatin-based chemotherapy similar to small cell lung cancer (1).

Peritoneal carcinoma in women (rarely men) is usually adenocarcinoma and should be treated like ovarian cancer stage FIGO III. Patients with a single small cell can be treated locally with surgery and/or radiotherapy. Adenocarcinoma with colon cancer profile should be treated the same as patients with metastatic colon adenocarcinoma since this improves their outcome (1).

Surgery can be performed in individual patients with CUP, particularly in the favorable subset. The multidisciplinary team should discuss patients with a single brain, liver, lung, or skin metastasis to review surgery's possibility because what appears to be a metastasis could easily be a primary tumor (11).

Radiation therapy can be a part of standard multimodal treatment for patients with isolated inguinal lymphadenopathy after surgery or patients with squamous cell metastases in neck lymph nodes. It can also be used for palliative purposes, such as spinal cord compression or superior vena cava syndrome (11).

The unfavorable subset group includes metastatic adenocarcinoma in the liver, squamous cell cancer of the abdominal/peritoneal cavity, malignant ascites (nonpapillary), multiple brain, lung/ pleural, or bone metastases (1).

Most patients with CUP have an unfavorable prognosis, despite combined chemotherapeutic therapy. It has been shown that most patients respond to therapy based on platinum, so doublets with platinum and new-generation compounds such as taxanes or gemcitabine may be a reasonable choice $(6,12)$. Triplets are considered more toxic and are not recommended $(13,14)$. Empirical chemotherapy should be reserved for patients whose molecular profile is unable to predict tumor origin (15).

\section{CONCLUSION}

Cancer of unknown primary remains a complex diagnostic as well as a therapeutic challenge. Most patients still have a poor prognosis despite multimodal treatment. There are still no standard chemotherapy protocols that would make significant progress in survival. Dual platinum chemotherapy is the most common choice because the addition of a third agent has not shown survival benefit. It is essential to identify CUP patients subgroups that can benefit from a specific treatment procedure, avoiding unnecessary diagnostic procedures. Multimodal treatment with surgery, radiotherapy, and chemotherapy represents the best modality treatment for cancer of unknown primary.

\section{REFERENCES}

1. Abraham J and Gulley JL. The Bethesda Handbook of Clinical Oncology. Carcinoma of Unknown Primary. Fifth Edition. Philadelphia: PA: Wolters Kluwer; 2019.

2. Pavlidis N. Cancer of unknown primary: biological and clinical characteristics. Ann Oncol 2003;14 (Suppl 3):iii11-18. 
3. Pavlidis N, Briasoulis E, Hainsworth J, Greco FA. Diagnostic and therapeutic management of cancer of an unknown primary. Eur J Cancer. 2003; 39: 1990-2005.

4. Hrvatski zavod za javno zdravstvo, Registar za rak Republike Hrvatske. Incidencija raka u Hrvatskoj 2017., Bilten 42, Zagreb, 2020.

5. Altman E, Cadman E. An analysis of 1539 patients with cancer of unknown primary site. Cancer. 1986; 57(1):120-4.

6. Kramer A., Hubner G., Schneeweiss A., Folprecht G and Neben K. Carcinoma of unknown primary - an orphan disease. Breast Care. 2008; 3, 164-170.

7. Buttar A, Lambert L, Liebmann J, Pieters R. Cancers of Unknown primary. In: Pieters R, Liebmann J, eds. Cancer Concepts: A Guidebook for the Non-Oncologist. Worcester, MA: University of Massachusetts Medical School; 2015.

8. Casciato DA. (2006). In: Manual of Clinical Oncology, ed. DA. Casciato, 5th edn. Philadelphia, PA:Lippincott Williams and Wilkins, pp. 402-14.

9. Culine S. Prognostic factors in unknown primary cancer. Semin Oncol. 2009; 36(1):60-4.
10. Pavlidis $\mathrm{N}$ and Pentheroudakis G. Cancer of unknown primary site. Lancet. 2012; 379, 1428-1435.

11. Hanna L, Crosby T, Macbeth F. Practical Clinical Oncology. Second edition. Cambridge: Cambridge University Press; 2015.

12. https://www.nccn.org/professionals/physician_gls/ pdf/occult.pdf

13. Hainsworth JD, Spigel DR, Clark BL, Shipley D, Thompson DS, Farley C et al. Paclitaxel/carboplatin/ etoposide versus gemcitabine/irinotecan in the firstline treatment of patients with carcinoma of unknown primary site: a randomized, phase III Sarah Cannon Oncology Research Consortium Trial. Cancer J. 2010; 16(1):70-5.

14. Amela EY, Lauridant-Philippin G, Cousin S, Ryckewaert T, Adenis A, Penel N. Management of "unfavourable" carcinoma of unknown primary site: synthesis of recent literature. Crit Rev Oncol Hematol. 2012; 84(2):213-23.

15. Losa F, Soler G, Casado A, Estival A, Fernandez I, Giménez S, Longo $\mathrm{F}$ et al. SEOM clinical guideline on unknown primary cancer (2017). Clin Transl Oncol. 2018; 20(1): 89-96.

Sažetak

\section{LIJEČENJE TUMORA NEPOZNATOG PRIMARNOG SIJELA}

\section{Andrašek, M. Ravlić, M. Mikulandra, F. Cmrečak, S. Bilić Knežević i L. Beketić-Orešković}

Rak nepoznatog primarnog sijela je najčešće agresivni metastatski tumor sa srednjim preživljenjem bolesnika od 6 do 9 mjeseci. Histološki se uglavnom radi o adenokarcinomu, a ako se dijagnosticira primarno sijelo, to je najčešće gušterača ili pluća. Kad god je to moguće, potrebno je učiniti biospiju, kako bi se tumor nepoznatog primarnog sijela klasificirao na jedan od slijedećih entiteta: adenokarcinom, slabo diferencirani karcinom s karakteristikama sličnim adenokarcinomu, karcinom pločastih stanica, neuroendokrini karcinom ili slabo diferencirani tumor. Nakon određivanja glavnog tipa tumora, pomoću imunohistokemijskih metoda određuje se podtip. Kod oligometastatske bolesti postoji mogućnost kirurškog liječenja. Radioterapija se koristi kao dio multimodalnog liječenja. Većina bolesnika s tumorom nepoznatog primarnog sijela ima nepovoljnu prognozu, unatoč primjeni više kombinacija kemoterapijskih lijekova, a niti jedan protokol se ne može preporučiti kao standardna terapija.

KLJUČNE RIJEČI: rak nepoznatog primarnog sijela, prognoza, liječenje 